УДК: 351.342

DOI: https://doi.org/10.32689/26172224-2019-17-2-87-96

\section{Карпюк Сергій Васильович,} аспірант, Міжрегіональної Академії управління персоналом, 03039 м. Київ, вул. Фрометівська, 2, тел.: (097) 76868 41, е-таil: Sergei.karpjuk@meta.ua

ORCID: 0000-0002-7579-4867

\section{Карпюк Сергей Васильевич,}

аспирант, Межрегиональная Академия управления персоналом, 03039, г. Киев, ул. Фрометовская, 2, тел.: (097) 7686841 , e-mail:Sergei.karpjuk@meta.ua

ORCID: 0000-0002-7579-4867

Karpyuk Sergey Vasilievich, graduate student, Interregional Academy of Personnel Management, 03039, Kyiv, Str. Frometivska, 2, tel.: (097) 76868 41, e-mail: Sergei.karpjuk@meta.ua

ORCID: 0000-0002-7579-4867

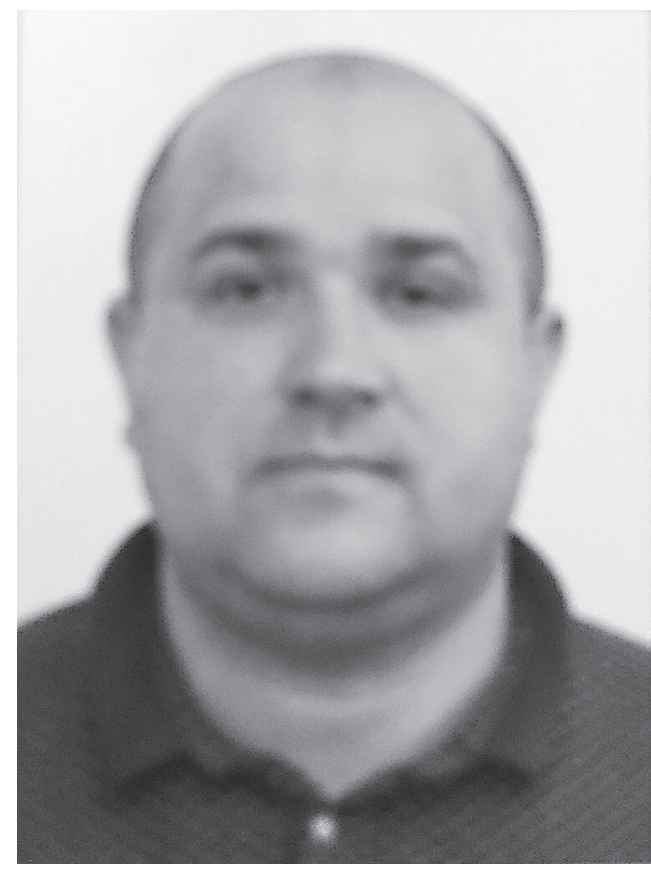

\title{
АКТУАЛЬНІ ТЕОРЕТИКО-МЕТОДОЛОГІЧНІ АСПЕКТИ ДОСЛІДЖЕННЯ ФЕНОМЕНУ “ДЕРЖАВНЕ УПРАВЛІННЯ” В ПАРАДИГМІ РОЗВИТКУ СУЧАСНОГО ПУБЛІЧНОГО АДМІНІСТРУВАННЯ
}

Анотація. Розглядаються такі основоположні теоретичні поняття системи державного управління, як “держава”, “державне управління”, “державна служба”, “публічне управління”, “публічне адміністрування”, “державно-управлінська еліта”. Звертається увага на те, що проблеми трансформації державної служби, насамперед, зумовлені радикальними трансформаціями самої держави і береться за основу те, що держава в майбутньому все більше буде розглядатися саме як специфічний інструмент (засіб, механізм) організації функціонування соціуму. Підкреслюється, що державне управління має власну специфіку і значною мірою залежить від особливостей суспільного розвитку. Обгрунтовується теза стосовно того, що державне управління - це специфічний вид діяльності органів держави, який здійснюється за двома видами: виконавчим і розпорядчим, та має організуючий вплив, насамперед, у трьох суспільних сферах: економічній, соціально-культурній та адміністративній. Зазначається, що державна служба як складний соціальний феномен 
може розглядатися як урядова служба і як служба громадянська. Звертається увага на те, що у більшості випадків державну службу пояснюють як діяльність професійну, тобто їі здійснюють спеціально відібрані й професійно підготовлені фахівці. При цьому слід не поєднувати феномени “державні службовці” і “бюрократія”, які мають різний сенс і пояснення. Аналізуються сутнісні значення понять “публічне управління” і “публічне адміністрування”, “державно-управлінська еліта”. Підкреслюється, що державна служба має бути значною мірою деполітизованою, професійною діяльністю.

Обгрунтовано: оскільки державна служба виконується спеціально підібраними, професійно підготовленими працівниками, державними службовцями, то під час розгляду різних аспектів державної служби доречно вжити термін “державний апарат”. Фактично слід брати до уваги саме те, що такий термін має два основних значення: а) як певна організаційна структура; б) як кадровий склад певної структури в системі державної служби. Вважаємо, що друге значення є більш точним і конкретним.

Ключові слова: держава, державне управління, державна служба, публічне управління, публічне адміністрування, державно-управлінська еліта.

\section{АКТУАЛЬНЫЕ ТЕОРЕТИКО-МЕТОДОЛОГИЧЕСКИЕ АСПЕКТЫ ИССЛЕДОВАНИЯ ФЕНОМЕНА “ГОСУДАРСТВЕННОЕ УПРАВЛЕНИЕ” В ПАРАДИГМЕ РАЗВИТИЯ СОВРЕМЕННОГО ПУБЛИЧНОГО АДМИНИСТРИРОВАНИЯ}

Аннотация. Рассматриваются такие основоположные теоретические понятия системы государственного управления, как “государство”, “государственное управление”, “государственная служба”, “публичное управление”, “публичное администрирование”, “государственно-управленческая элита”. Обращается внимание на то, что проблемы трансформации государственной службы, в первую очередь, обусловлены радикальными трансформациями самого государства и берется за основу то, что государство в общем все больше будет рассматриваться именно как специфический инструмент (способ, механизм) организации функционирования социума. Подчеркивается, что государственное управление имеет собственную специфику и в большей степени зависит от степени развития общества. Обосновывается тезис относительно того, что государственное управление - это специфический вид деятельности органов государства, который осуществляется посредством двух видов такой деятельности: исполнительной и распорядительной и имеет организующее влияние в трех общественных сферах: экономической, социально-культурной и административной. Указывается на то, что государственная служба как сложный социальный феномен может рассматриваться как правительственная служба и как служба гражданская. Обращается внимание на то, что в большинстве случаев государственную службу объясняют и как деятельность профессиональную, то есть ее осуществляют специально подготовленные специалисты. При этом нельзя объединять феномены “государственные служащие” и “бюрократия”, которые имеют различный смысл 
и объяснение. Анализируются существенные особенности понятий “публичное управление”, “публичное администрирование”, “государственно-управленческая элита”. Подчеркивается, что государственная служба должна быть значительным образом деполитизированной, профессиональной деятельностью.

Обосновано: поскольку государственная служба выполняется специально подобранными, профессионально подготовленными работниками, государственными служащими, то при рассмотрении различных аспектов государственной службы следует употреблять термин "государственный аппарат". Фактически следует принимать во внимание именно то, что такой срок имеет два основных значения: а) как определенная организационная структура; б) как кадровый состав определенной структуры в системе государственной службы. Считаем, что второе значение является более точным и конкретным.

Ключевые слова: государство, государственное управление, государственная служба, публичное управление, публичное администрирование, государственно-управленческая элита.

\title{
ACTUAL THEORETIKO-METHODOLOGICAL ASPECTS OF RESEARCH OF THE PHENOMENON "STATE ADMINISTRATION" IN PARADIGM OF DEVELOPMENT OF MODERN PUBLIC ADMINISTRATION
}

\begin{abstract}
Such basic theoretical concepts of the system of state administration as "state", "state administration", "government service", "public management", "public administration", "state-administrative elite are examined". Attention applies on that, one hundred the problems of transformation of government service are above all things conditioned radical transformations of the state and embarks on basis that the state in general all anymore will be examined exactly as a specific instrument (method, mechanism) of organization of functioning of sociuma. It is underlined that state administration has an own specific and in a greater degree depends on the degree of development of society. A thesis is grounded in relation to that state administration is a specific type of activity of organs of the state, which is carried out by means of two types of such activity - executive and active and has an organizing influence in three public spheres - economic, social'nokul'turnoy and administrative. Specified on that government service, as difficult social phenomenon, can be examined as governmental service and as service civil. Attention applies on that in most cases government service is explained and as activity professional, that it is carried out by specially geared-up specialists. It is thus impossible to unite the phenomena "civil servants" and "bureaucracy", which have different sense and explanation. The substantial features of concepts "Public management" and "public administration", "state-administrative elite, are analysed". It is underlined that government service must be considerable appearance by depolitizirovannoy, professional activity.

It is substantiated that since the public service is carried out by specially selected, professionally trained employees, civil servants, the following general re-
\end{abstract}


marks should be made: often when considering various aspects of the civil service, the term "state apparatus" is used. In fact, it should be borne in mind that this term has two main meanings: a) as a certain organizational structure; b) as a personnel structure of a certain structure in the system of civil service. We believe that the second meaning is more precise and concrete.

Keywords: state, state administration, government service, public management, public administration, state-administrative elite.

Постановка проблеми. Державне управління як наукова галузь існує у багатьох країнах нещодавно. В Україні, наприклад, воно з'явилося лише у 1997 р., коли в спеціальній Постанові Кабінету Міністрів України у переліку наукових ступенів і звань доктора i кандидата наук з'явився запис “державне управління”. У зв'язку з цим неабияку актуальність має науково-теоретичне осмислення сутності цього поняття, тих понять, які насамперед його обгрунтовують, пояснюють.

Аналіз останніх досліджень та публікацій. Беручи до уваги напрацювання таких відомих зарубіжних вчених, як В. Ардов, Г. Атаманчук, К. Боумен, Т. Веблен, Е. Воутелайтен, У. Гамільтон, М. Деван, Дж. Івацевич, А. Кемпінські, Д. Кендрик, Т. Коно, К. Кунць, Марр, М. Мескон, Д. Норт, А. Рибаков, Ю. Шмідт та ін., українських - А. Боровська, О. Бухтатий, Н. Драгомирецька, В. Князєв, В. Козаков, В. Ліпкан, О. Радченко, С. Романенко, О. Пархоменко-Куцевіл, Н. Нижник, В. Оболенський, В. Рибкало, Г. Щокін та інших, є можливість виокремити (на думку автора) коло проблем теоретичного дослідження феномену “державне управління", яке окреслюється такими основними поняттями: “держава” (сучасна); “державне управління”; “державна служба”; “публічне управління”; “публічне адміністрування”; “державно-управлінська еліта".

Мета статті - проаналізувати актуальні теоретико-методологічні аспекти дослідження феномену “державне управління" в парадигмі розвитку сучасного публічного адміністрування.

\section{Виклад основного матеріалу} дослідження. Наведений перелік термінів (сентенцій) нам видається основним, а інші багато в чому є похідними від названих.

Оскільки кожне 3 наведених понять потребує грунтовного і всебічного дослідження, визначимо і вкажемо лише на ті найважливіші його складові й особливості, які є недостатньо дослідженими у державному правлінні, або й взагалі далися надто взнаки саме в останній час.

Держава. Як людське утворення, як механізм поєднання великих груп людей у соціум для спільного життя, сучасні держави достатньо радикально трансформуються. Так, у майбутньому, цілком об'єктивно, вимогливість громадян, суспільства щодо дієздатності держави буде зростати. Багато держав нині вже не спроможні реально забезпечити права і свободи людини (громадянина), а тому в май- 
бутньому швидше за все спостерігатимемо помітну відмову від чисто ліберальної моделі іi функціонування. Держава все більше розглядатиметься як специфічний інструмент (засіб, механізм) організації функціонування соціуму. Отже, принципово змінюватиметься державне управління, діяльність державних службовців, їх взаємини із громадою (соціумом).

Державне управління. Розмірковуючи про долю управління загалом, а це має пряме відношення i до державного управління, відомий російський фахівець у галузі державного управління Г. В. Атаманчук зазначає, що система управління 3 часом все більше тяжітиме до власного оновлення, вдосконалення. Він пише: “Неважко побачити певний взаємозв’язок між станом і потенціалом управління, з одного боку, i динамікою розвитку того чи іншого суспільства, з другого. Де управління “дрімає” або безпорадне, там i суспільство у всіх своїх сферах перебуває у застої, розвалі, конфліктах, відсталості і занедбаності” [1, с. 73]. I застерігає: “При цьому принципово важливо, щоб відбувся саме прорив, а не розрив історичного ланцюга розвитку, відмова від минулої культури, розвал створеного століттями" [1, с. 79]. У цьому випадку маємо застерегти, що історичні, теоретичні i практичні напрацювання, у тому числі в галузі державного управління в Україні, навіть за так званої радянської доби, не можна стовідсотково відкидати як негатив: треба таку практику реально й об'єктивно осмислювати 3 бажанням запозичення кращих елементів, що можуть слугувати позитивом і сьогодні.
В основі аналізу державного управління, державної служби має бути розуміння того, що держава взагалі, за визначенням С. Куріца i В. Воробйова “являє собою одну 3 різновидностей систем живої природи, але створеною людьми організацію (організаційну систему) тобто артефакт" [2, с. 70]. Один із основоположників кібернетики Н. Вінер 3 цього приводу писав: “Природа, у широкому сенсі цього слова, може i повинна слугувати не тільки джерелом задач, які я вирішую, а й підказує апарат, зручний для їх вирішення" [3, c. 44].

Державне управління, як специфічний вид діяльності органів держави, у переважній більшості випадків сьогодні у теоретичному плані подається через два основних види такої діяльності: виконавчий i розпорядчий. Обидва вони забезпечують організуючий вплив на суспільні відносини фактично у трьох сферах - економічній, соціально-культурній і адміністративній [4, c. 147]. Державному управлінню також властиві всі ознаки виконавчої влади, а спрямоване воно, головним чином, на виконання законів, інших нормативно-правових актів, на забезпечення сталого суспільного розвитку.

Є підстави стверджувати, що у сучасній Україні формується фактично принципово нова парадигма державного управління, із найважливіших складових якої є управлінська культура державних службовців та розвиток у них ціннісно-орієнтованої комунікації. Такі складові логічно позначені у Законі України "Про державну службу” від 10.12.2015 р., 
у “Загальних правилах етичної поведінки ДС та ПоМС”, затверджених наказом Національного агентства України з питань державної служби від 05.08.2016 р. Крім того, відповідні стандарти державної служби прописані у "Правилах етичної поведінки державних службовців”, затверджених Постановою Кабінету Міністрів України від 11.02.2016 р. № 65.

Державна служба. Тут слід звернутися до думки відомого російського політолога В. Ф. Халіпова, який вважає, що державна служба як складний соціальний феномен (State Service), розуміється і пояснюється у двох основних іпостасях: а) як урядова служба (government service); б) як громадянська служба (civel service) [5, c. 476]. Таке трактування поняття “державна служба” почало складатися ще у добу просвітницького абсолютизму (XVIII ст.). Тоді вже почала формуватися і поступово домінувати думка про те, що державна служба це вже служба не царю (самодержавцю, монарху) але державі, а отже, суспільству. Адекватно цьому змінювалося і розуміння феномену “державний службовець” (civil/public servant; government official). Малося на увазі, що таким службовцем є той, хто працює в органах державної влади [5, с. 480].

Вважаємо, що не слід спрощено поєднувати, уособлювати "державну службу” і “державну бюрократію”, як це роблять, зокрема, автори навчального посібника "Правові аспекти управління навчальним закладом" (К., 2016) В. Л. Павленко і В. В. Павленко [6], тому що “державна служба” - це практично професійна і відповідальна діяльність у державних органах, а “бюрократія” це "правління функціонерів", “влада (фр. Burean) контор-установ”, тобто “бюрократія" здебільшого розуміється і пояснюється як певна негативна субстанція.

Поряд $з$ державними управлінцями, які часто асоціюються з бюрократією, є ще своєрідний соціальний прошарок, який називають технократією. На думку французького дослідника М. Ферро, цей соціальний прошарок у XX ст. певною мірою зрісся з адміністрацією. "Якщо на Заході, пише Ферро, - бюрократія забезпечувала незалежне від політичної і соціальної кон'юнктури функціонування системи, що слугувала перепоною для різних змін, то в СРСР, навпаки, вона все більше ототожнювала себе 3 політичною владою, яка, разом з тим, звинувачувала їі у тих самих гріхах, а громадська думка, нападаючи на бюрократію, виступала з критикою режиму і системи в цілому” [7, с. 357]. 3 цього приводу дуже влучно висловився російський вчений Л. Карпінський, який стверджує, що в добу СРСР “бюрократія отримала разом з державою необмежений доступ до управління економікою і культурою, проникнувши буквально в усі сфери людської життєдіяльності" [7, с. 361]. Ще у 1941 р. Д. Берхем у своїй книзі "Революція менеджерів" стверджував, що технократи (управлінці) стали реальністю, проникли і у державне управління. Це вже зовсім інший аспект проблеми.

Аналізуючи практичну діяльність державних службовців, найважливіше, вважаємо, брати до уваги те, що державне управління (у сфері якого такі службовці діють) є одним із різ- 
новидів соціального управління, ще точніше - управління людьми. Тут слід погодитися 3 думкою відомого американського політолога Ф. Фукуями про те, що нове управління, як феномен взагалі, буде характеризуватися суттєвим зростанням саме державного управління. Інша справа, що таке управління, з часом, матиме принципово інші ознаки, характеристики, зміст.

Публічне управління і публічне адміністрування. Публічність державної служби - одне з центральних понять у державному управлінні, яке пояснюють досить неоднозначно, часто асоціюючи i з гласністю [8]. Деякі дослідники (зокрема С. Федорова) небезпідставно стверджують, що публічність і гласність - деякий інструмент реалізації публічності [9, c. 964-968].

"Публічність" як більш широке поняття, ніж “гласність” - це безпосередній інструмент тісного поєднання державної влади і громадянського суспільства. Без такого поєднання державна влада навряд чи зможе себе зреалізувати, та і на рівень свідомої підтримки громадянами державної влади сподіватися досить важко.

Достатньо оптимальне визначення феномену “публічність" саме у державній службі тим і ускладнюється, що таку публічність досить часто розглядають саме у конкретній сфеpi народногосподарської діяльності. Якщо йдеться про публічність у сфеpi соціально-економічної, господарської (підприємницької) діяльності, то йдеться про доступність громадян до реального знання щодо діяльності підприємницьких структур (відкритість ведення бізнесу) [10, с. 275].
За такої ситуації прочитання терміна "публічність" вважаємо найдоцільніше розглядати в контексті терміна “публічне управління”. Відомо, що вперше використав його відомий англійський дослідник Д. Кілінг, який під ним розумів “пошук найкращих способів використання ресурсів задля досягнення пріоритетних цілей держави” [11, с. 605].

Підтвердження такого визначення знаходимо і в ряді нормативного характеру документах державницького рівня, що були прийняті в сучасній Україні. Так, у ст. 45 нової редакції Закону України "Про державну службу” від 2015 р. публічність державної служби закріплена такими обов’язковими умовами ㄲï практичного функціонування, як: публічні звіти керівників органів виконавчої влади перед громадськістю про діяльність конкретного державного органу; інформація про діяльність державних органів у 3MI, зокрема, на веб-сайтах окремих органів виконавчої влади. Нагадаємо, що принцип публічності державної служби певною мірою проводиться і у деяких Указах Президента України, зокрема в Указі "Про стратегію державної кадрової політики на 2012-2020 рр.” [12] та ін.

Є чимало підстав також погодитися з думкою О. Амосова та Н. Гавкалової у тому плані, що “для того щоб відбулася трансформація державного управління в публічне, необхідно виконати кілька умов. Насамперед це стосується формування інституційного забезпечення управління у суспільстві, в якому фактично одночасно існує кілька моделей взаємодії та соціальних сегментів: солідарис- 
тиче суспільство, консорції, конвіксії та правова соціальна держава [13, c. 17].

Доречною є думка авторів "Енциклопедичного словника 3 державного управління" [11] стосовно того, що публічне адміністрування - це максимальна відкритість у реалізації державної політики: якщо державна політика здійснюється шляхом публічної діяльності, то така діяльність і є публічним адмініструванням [11, c. 605]. У цьому контексті доречною є ідея прийняття спеціального Кодексу про публічну службу в Україні.

Державно-управлінська еліта порівняно новий, мало науково опрацьований термін, що в умовах надмірної бюрократизації державного управління, на жаль, набуває негативного відтінку.

По-перше, часто невиправдано змішують поняття "політична еліта" та “державно-управлінська еліта”, асоціюють їх, хоча особливих підстав робити це немає.

По-друге, аби такі асоціації були менш відчутними, державні управлінці мають бути максимально деполітизованими. Завдання державного службовця - максимально дієво реалізувати державну політику. Але якщо він їі поціновує як особистість з політичної точки зору, то це вже справа власного людського сумління й свідомості. У цьому плані зрозуміло, чому в ряді держав статус державного службовця політизують навіть у правовому плані. I хоча політика i державне управління (як і політичне та державне управління) ще з давніх часів (Греція, Рим, Китай) тісно переплітаються, слід брати до уваги, що часто політика пояснюється: як своє- рідна “чиста”, виокремлена сутність; як специфічна діяльність усіх суб’єктів суспільно-політичного життя, що регулює їх взаємовідносини; як спосіб досягнення відповідних цілей; як сукупність питань і подій державного і громадського життя [14, c. 265]. Тобто політичну і державну діяльність все ж значною мірою необхідно “розмежовувати”.

\section{СПИСОК ВИКОРИСТАНИХ ДЖЕРЕЛ}

1. Атаманчук Г. В. Теория государственного управления: курс лекций. - М.: Юрид. лит., 1997. - 512 с.

2. Курии С. Я. Болезни государства. Диагностика патологий системы государственного управления и права: монография / С. Я. Куриц, В. П. Воробьев. - Моск. гос. ин-т междунар. отношений (ун-т) МИД России. - М.: МГИМО (У) МИД России, 2009. - 472 с.

3. Винер Н. Кибернетика. - 2-е изд.: пер с англ. - М., 1968. - 521 с.

4. Політологічний енциклопедичний словник / упоряд. В. П. Горбатенко; за ред.: Ю. С. Шемчушенка, В. Д. Бабкіна, В. П. Горбатенка. 2-ге вид. допов. і переробл. - К.: Генеза, 2004. - 736 с.

5. Халипов В. Ф. Энциклопедия власти. - М.: Академ. проект; Культура, 2005. - 1056 c.

6. Павленко В. В., Павленко В. Л. Державна служба в Україні: підручник. - К.: ДП “Вид. дім "Персонал”, 2017. - 510 c.

7. 50/50 Опыт словаря нового мышления / под ред. М. Ферро и Ю. Афанасьева. - М.: Прогресс, 1989. 560 c.

8. Курии С. Я. Болезни государства. Диагностика патологий системы государственного управления и 
права: монография / С. Я. Куриц, В. П. Воробьев. - Моск. гос. ин-т междунар. отношений (ун-т) МИД России. - М.: МГИМО (У) МИД России, 2009. - $472 \mathrm{c.}$

9. Федоров $C$. $C$. Принцип гласності у державному фінансовому контролі: межі трансформації // Форум права. - 2012. - № 4. - С. 963-969. [Електронний ресурс]. - Режим доступу: archive.gov.ua/ejourncls/ EP/2012-4/12 tcekmp.pdt25

10. Андрїв Н. М. Організація державного управління інноваційним розвитком вітчизняного підприємства у системі внутрішньої торгівлі // Глобальні та нац. проблеми економіки. - 2015. - Вип. 4. - 274-279 с.

11. Енциклопедичний словник 3 державного управління / уклад.: Ю. П. Сурмін, В. Д. Бакуменко, А. М. Міхненко та ін.; за ред. Ю. В. Ковбасюка, В. П. Трощинського, Ю. П. Сурміна. - К.: НАДУ, 2010. $-820 \mathrm{c}$.

12. Указ Президента України "Про стратегію державної кадрової політики на 2012-2020 роки” від 1 лютого 2012 р. № 45/2012 [Електронний ресурс]. - Режим доступу: http://zakon1.rada.gov.ua/laws/ show $/ 45 / 2012$

13. Амосов О. Ю., Гавкалова Н. Л. Симбіоз інституційних засад та архетипіки публічного управління // Публічне урядування. - Вип. № 2(3), червень 2016. - С. 16-22.

14. Халипов В. Ф. Власть. Кратологический словарь. - М.: Республика, 1997. - $431 \mathrm{c}$.

\section{REFERENCES}

1. Atamanchuk, G. V. (1997). Teoriya gosudarstvennogo upravleniya: kurs lektsiy [Theory of public administration: a course of lectures]. Moscow: Izd-vo Yuridicheskaya literatura [in Russian].
2. Kurits S. Ya., Vorobyev V. P. (2009). Bolezni gosudarstva. Diagnostika patologiy sistemy gosudarstvennogo upravleniya i prava [Diseases of the state. Diagnostics of pathologies of the system of public administration and law]. Moscow: MGIMO (U) MID Rossii [in Russian].

3. Wiener N. (1968). Kibernetika ili upravlenie i svyaz v zhivotnom i mashine [Cybernetics, or control and communication in the animal and the machine]. ( $2^{\text {nd }}$ ed.). Moscow: Sovetskoe radio [in Russian].

4. Shemchushenko Yu. S., Babkin V. D., Horbatenko V. P. (Eds.). (2004). Politolohichnyi entsyklopedychnyi slovnyk [Politologic encyclopedic dictionary]. ( $2^{\text {nd }}$ ed., rev.). Kyiv: Geneza [in Ukrainian].

5. Khalipov V. F. (2005). Entsiklopediya vlasti [Encyclopedia of power]. Moscow: Akademicheskiy proekt; Kultura [in Russian].

6. Pavlenko V. V., Pavlenko V. L. (2017). Derzhavna sluzhba v Ukraini [Civil service in Ukraine]. Kyiv: DP "Vyd. dim "Personal" [in Ukrainian].

7. Ferro M., Afanasyeva Yu. (Eds.). (1989). 50/50 Opyt slovarya novogo myshleniya [50/50 Experience of the Dictionary of New Thinking]. Moscow: Progress [in Ukrainian].

8. Kurits S. Ya., Vorobyev V. P. (2009). Bolezni gosudarstva. Diagnostika patologiy sistemy gosudarstvennogo upravleniya i prava [Diseases of the state. Diagnostics of pathologies of the system of public administration and law]. Moscow: MGIMO (U) MID Rossii [in Russian].

9. Fedorov S. Ye. (2012). Pryntsyp hlasnosti u derzhavnomu finansovomu kontroli: mezhi transformatsii [The principle of publicity in public financial control: the limits of transformation]. Forum prava - Law Forum, 4, 963-969 [in Ukrainian]. 
10. Andriiv N. M. (2015). Orhanizatsiia derzhavnoho upravlinnia innovatsiinym rozvytkom vitchyznianoho pidpryiemstva u systemi vnutrishnoi torhivli [Organization of state management of innovative development of the domestic enterprise in the system of internal trade]. Hlobalni ta natsionalni problemy ekonomiky - Global and national problems of the economy, 4, 274-279 [in Ukrainian].

11. Kovbasiuk Yu. V., Troshchynskyi V. P., Surmin Yu. P. (Eds.). (2010). Entsyklopedychnyi slovnyk z derzhavnoho upravlinnia [Encyclopedic Dictionary of Public Administration]. Kyiv: NADU [in Ukrainian].

12. Ukaz Prezydenta Ukrainy "Pro stratehiiu derzhavnoi kadrovoi polityky na 2012-2020 roky" : vid 1 liutoho
2012 roku, № 45/2012 [Decree of the President of Ukraine "On the Strategy of the State Personnel Policy for 2012-2020" from February 12012 , № 45/2012]. zakon.rada.gov.ua. Retrieved from http://zakon1.rada.gov. ua/laws/show/45/2012 [in Ukrainian].

13. Amosov O. Yu., Havkalova N. L. (2016). Symbioz instytutsiinykh zasad ta arkhetypiky publichnoho upravlinnia [Symbiosis of institutional foundations and archetype of public administration]. Publichne uriaduvannia - Public administration, 2 (3), 16-22 [in Ukrainian].

14. Khalipov V.F. (1997). Vlast. Kratologicheskiy slovar [Power. Cratological dictionary]. Moscow: Respublika [in Russian]. 